\title{
V.E. d'Assonville
}

TOTIUS

\section{EN SY UNIVERSITEIT}

Van die besembosse van Burgersdorp na die gragte van Amsterdam

As die digter S.J. Pretorius in 1950, 'n jaar voor die selfstandigwording van die Potchefstroomse Universiteit vir Christelike Hoër Onderwys, 'n ,Alma-Mater"-lied dig ${ }^{1)}$, dan maak hy 'n kostelike historiese greep as hy die ontstaan van die Universiteit vertolk met die aanhef "Gebore uit die nag van smaad". Hierdie „nag van smaad" word op sy donkerste as die Tweede Vryheidsoorlog die Teologiese Skool van Burgersdorp feitlik tot stilstand bring en die twee Boererepublieke 'n puinhoop gemaak word. Dan bevind J.D. du Toit, die Kaapse rebel, hom teen die einde van 1900 saam met ander Kapenaars in ballingskap in Amsterdam waar hy aan die Vrye Universiteit van Abraham Kuyper diep onder die indruk kom van die idee van 'n Christelike Universiteit en die Christelike wetenskap. En dáár het hierdie idee - as 'n redmiddel van 'n volk in sy nood - by hom en sy studievriend, Ferdinand Postma, gestalte gekry:

\footnotetext{
„As ons dan ook saans langs die stil gragte gewandel het, het die gesprek maar altyd weer oor daardie benarde toestand van ons volk gegaan. Ons het egter nie net gemurmureer en geklaag nie maar telkens die vraag bespreek wat gedoen moet word om ons volk in die toekoms weer op te hef. Al redenerend kom ons dan tot die gevolgtrekking dat Christelike hoër onderwys 'n magtige faktor sal wees om ons volk weer op die regte spoor te bring. Die Vrije Universiteit het ons proefondervindelik voor oé gestel wat 'n hoërskool (universiteit) vir die volkslewe beteken; en prof. Woltjer het ons geleer dat dit op die hoë berge wel stil en eensaam is, dat daar nie baie mense kom nie maar dat daar in die stilte die sneeu gevorm word wat straks in strome neerdaal om die vlaktes met vrugbare vog te besproei.
}

(1) Hiendie gedig word soms verkeerdelik aan Totius toegeskryf. Vergelyk die notules van die Studenteraad van die PU vir CHO, 25 November 1950, 10 Augustus 1951. 
Ek voel eintlik 'n bietjie sku om hier te vertel van al die planne wat ons saam gefabriseer het. Dit lyk so baie na produkte van aanmatiging, oormoed en jeugdige fantasie. Maar ek het sedert geleer dat daar verskil is tussen fantasie as 'inbeelding' en fantasie as 'uitbeeldende vermoë'.

Die vraag wat ons gestel het, was: Wat is die moontlikhede van 'n Christelike hoërskool vir teologie, lettere, matesis, natuurkunde, ensovoorts? Moenie vergeet ne dat in Suid-Afrika reeds 'n Teologiese Skool met Literariese Departement bestaan het. Die gedagte was om soveel moontlik aan te sluit by wat voorhande was. Vandaar die enigsins weidse beplanning."

\section{So skryf Totius in Koers van November 19392).}

Die eerste „beplanning" van die Chistelike Universiteit vir SuidAfrika het dus daar langs die gragte van Amsterdam begin. Selfs die studiekoers van F. Postma was in hierdie plan ingesluit. Die geval was naamlik dat Postma alreeds aan die Vrije Universiteit ingeskryf was om in die teologie te studeer, maar ter wille van die grootse ideaal van 'n Christelike Universiteit in die vaderland, het Totius hom beinvloed om van studiekursus te verander. „Ingevolge ons toekomsbesprekinge het ek gemeen dat hy van koers moes verander”, vertel Totius verder. „Hoe om dit gedoen te kry? Professor Postma het hom baie aangetrokke gevoel tot die teologie, en hy is iemand wat hom nie maklik uit die veld laat slaan as dit 'n vaste voorneme geld nie"3). Maar Totius se voorstel is aanvaar en Postma het verder in die Klassieke gestudeer en in 1903 die graad „Litterarum humaniorum candilatus” (L.H.C.) met lof behaal. Later sou dit blyk wat 'n geweldige bate hierdie skynbaar klein voorstel van Totius en die beslissing van Ferdinand Postma vir die toekomstige Universiteit sou hê.

Dit was nie al nie. As student in Amsterdam was Totius so besield met die gedagte om in Suid-Afrika 'n Christelike Universiteit op

(2) Versamelde Werke, 1977, decl 8, p. 459.

(3) A.w. 
te rig dat hy selfs op ' $n$ dag in 1901 die trein na Kampen gehaal het om die beroemde Herman Bavinck daaroor te gaan raadpleeg ${ }^{4)}$. Selfs in die buiteland het die ideaal om die Afrikaanse volk te lei met 'n Christelike Universiteit, 'n passie geword, en self het hy dit later meesterlik saamgevat in die spreuk van Prins Willem van Oranje, naamlik „Vivat schola, vivat religio” - mag die skool lewe, mag die godsdiens lewe! ${ }^{5}$ )

Verplasing van die Teologiese Skool na Potchefstroom - die inisiatief van hierdie één man?

Oor die werklike deurslaggewende motiewe vir die verplasing van die Teologiese Skool van dic Gereformeerde Kerk vanaf Burgersdorp na Potchefstroom, is die laaste woord nog nie gesê nie - veral wat betref die rol wat dr. J.D. du Toit vanaf einde 1903 en begin 1904 as predikant gespeel het. Hy was nie in die idec van verplasing as sodanig die eerste dryfveer nie, maar beslis in die feit dat dit na Potchefstroom moes plaasvind. Sy ywer vanuit sy eic gemeente (Potchefstroom) was so oortuigend en selfs so "berekenend" dat hy, feitlik man-alleen, die sinode van Middelburg, Kaap, van 11 tot 28 April 1904 vir sy standpunt kon oorhaal ${ }^{6)}$.

Die vraag kom onwillekeurig op: Hoe was dit tog moontlik dat J.D. du Toit 'n hele sinode kon beweeg om van alle plekke Potchefstroom te kies? Hy was op daardie tydstip nog 'n onervare jong man van 27 jaar en was nog skaars ses maande lank predikant. Daarby moet onthou word dat die Kuratore van die Gereformeerde Kerk 'n cenparige aanbeveling gedoen het dat die

(4) Sicn my Dr. J.D. du Toit se opleiding en vorming as predikant (ongepublisecrd), Th.M.-verhandeling, 1971, p. 68.

(5) V.W., a.w., p. 463.

(6) Die Kinhthert, I Junic 1904, V.W., a.w., p. 106 c.v. 
plek Steynsburg moes wees ${ }^{7}$; en hierdie voorstel is deur die deputate wat alreeds in 1897 benoem is, gesteun ${ }^{8)}$. Hoe is dit tog moontlik dat Potchefstroom skielik, onverwags in die guns van die meerderheid op die sinode van 1904 geval het?

Dit was die werk van die één man, dominee J.D. du Toit wat vandat hy teen die einde van 1903 predikant van Potchefstroom geword het, geen steen onaangeroerd gelaat het om sy tuisdorp die plek vir sy ideaal van 'n Christelike Universiteit te maak nie! En ons gaan nou feite bekend maak wat tot nog toe nie in geskiedenisboeke gepubliseer is nie:

Reeds op Kersfees 1903 lewer dr. J.D. du Toit 'n pleidooi voor sy Kerkraad dat die Teologiese Skool van Burgersdorp na Potchefstroom verplaas word en ,,desvereischt wordt door den kerkraad een plaats op ons kerkplein afgestaan om een gebouw voor de school te laten oprichten..."9).

Die predikant van Potchefstroom het van hierdie oomblik af verder geen gras onder sy voete laat groei nie en onder sy voorsitterskap word alreeds weer die volgende dag 'n drastiese besluit tot fondsinsameling geopen: „Algemeen wordt door de vergadering het plan goedgekeurd lijsten te laten tekenen om de verplaatsing onzer School naar Potchefstroom te bevorderen"10).

Maar dit is nie al nie. Nadat dr. J.D. du To't 'n deeglike organisasie in sy eie gemeente van stapel gestuur het, stuur hy ook voelers uit na Rustenburg, Pretoria, Heidelberg en Wolmaransstad en hy volg dit op met besoeke en openlike propaganda

(7) Notules Kuratore van die Geref. Kerk in S.A., 9 Desember 1903.

(8) Idem.

(9) Notules Kerkraad, Geref. Kerk Potchefstroom, 25 Desember 1903, art. 27.

(10) Idem, 26 Desember 1903, art. 4. 
vir verplasing na Potchefstroom en fondsinsamelings word in hierdie gemeentes geloods. So vind ons dit byvoorbeeld in die notuleboek van Rustenburg dat hy nie alleen hierdie gemeente se kerkraadsvergaderings op 25 en 26 Maart 1904 by woon nie, maar selfs voor die gemeente 'n vurige pleidooi lewer dat Potchefstroom die plek moet wees. Daarvoor, so het hy gesê, is R3 000 (R6 000) nodig! II)

Dat dr. J.D. du Toit en die kerkraad van Potchefstroom selfs pogings aangewend het om by al die Transvaalse gemeentes te kollekteer, blyk uit die brief van 15 April 1904, waarin 'n aanbod van $£ 3010$ (R6 020) plus gronde van die kerkraad, die stadsraad van Potchefstroom en die ,Landbouw-Syndicaat" gemaak word ${ }^{12)}$.

Behalwe hierdie daadwerklike pogings onder verskillende gemeentes, het dr. Du Toit ook nog artikels in die openbare pers geskryf om Potchefstroom te propageer ${ }^{13)}$ en om daarna die goeie besluit te beklemtoon 14 ). Luister net wat skryf hy in Fac et Spera van 1 April 1905 (vertaal):

„Potchefstroom dra ou en eerwaardige tradisies. Dit was die setelplek van Potgieter en sy veterane, die residensie van Transvaal se ou presidente. Dit was die bakermat van baie politieke en kerklike aksie. Op Potchefstroom se mark het die eerste botsing plaasgevind wat tot die Vryheidsoorlog gelei het, en in die distrik is die eerste beraadslaging gehou, nog voordat hulle na Paardekraal opgetrek het. Hier het ook die eerste skoot geval.

Hier het ds. Van der Hoff gewoon, die groot man van die Hervormde Kerk; hiervandaan is dic brief geskryf wat aanleiding was

(11) Nolulc Kerkraad, (icref. Kcrk Rustenburg, 25-26 Maart 1904, artt. 34, 37.

(I'I) Ilandelinge Sinode Cicref. Kcrk, Middelburg, 1904, bylac G.

(1.3) Ih, Ki, rkilhd, $15 \mathrm{~J}$ anuaric 1904.

(11) $1, \ldots, s \%, r .1$ April 1905. 
tot die afvaardiging van prof. D. Postma uit Nederland. Die besluit om ons Skool te stig het hier geval. En - menige twisvuur het hier gebrand. Die bevolking is nou nog oorwegend Afrikaans. Sal dit so bly in wese, nie in naam nie? Ons wil die beste hoop...

Hier het ons Skool neergestryk. Dit nestel te „Groenpunt”. Dit kan daar vir hom goed wees. Sal dit iets word? Dit hang van ons, seuns van Minerva, af. Te midde van soveel natuurskoon, vormweelde en kleureprag kan nie slegs bloei die harmonieuse digtersiel nie maar ook die fyn denkerskop. Mag dit so wees". 15)

\section{Totius die akademikus}

Sonder om afbreuk te doen aan die vakmanne wat van die begin af die fondamente van Potchefstroom se hoë akademiese standaarde gelê het (dink byvoorbeeld aan prof. F. Postma), kan met reg gesê word dat dit dr. J.D. du Toit was wat vanuit die Teologiese Skool met 'n buitengewone poging die wetenskap van die Teologie aan die voorpunt in Suid-Afrika geplaas het. Gaan kyk maar vandag na die leerplanne van veertien Teologiese vakke wat hy uitgewerk het en gaan lees sy diktate en jy kom baie gou agter: hier was 'n wetenskaplike wat geskool was in die beste wat Europa destyds kon bied. Daarby het hy ook nog by 'n gebrek aan genoeg dosente in die Literariese Afdeling ook nog Staatsleer, Etiek, Filosofie, Opvoedkunde en selfs Letterkunile gedoseer ${ }^{16)}$.

Daarby moet nog onthou word dat tot by inkorporasie van die Literariese Afdeling by die Universiteit van Suid-Afrika, was prof. Du Toit ook nog by tye rektor van die inrigting. Alle besluite wat tot by daardie stadium (1919) oor die akademiese ontwikkeling geneem is, het letterlik ook deur sy hande gegaan. Voortdurend was dit vir hom 'n vereiste: probeer die hoogste

(15) V.W., idem, p. 110-111.

(16) Almanak van die Geref. Kerk in S.A., 1912. 
wetenskaplike peil bereik. Later sê hy self: „Dit was die strewe om die Teologie volgens strenge metode en in wye omvang te doseer. En nou is daar wel 'n enkele keer die waarskuwende geroep van 'intellektualisme' gehoor; maar daarteenoor is volgehou dat die egte vroomheid nooit deur slordige wetenskap gedien kan word nie" 17).

Een van die mooiste bewyse van akademiese erkenning, is dat die Kaapstadse Universiteit op 20 Februarie 1915 die graad D.Div. as 'n eretoekenning aan Totius maak - 'n unieke erkenning deur die grootste Suid-Afrikaanse Engelstalige Universiteit van destyds ${ }^{18)}$.

Dat hierdie Potchefstromer nege doktorsgrade (waarvan twee in die buiteland) ontvang het, is in Suid-Afrika 'n ongeëwenaarde akademiese prestasie ${ }^{19)}$

Die gewetensklousule en inkorporasie

Totius se taak as professor van die Teologiese Skool het hom egter spoedig in 'n ander, bitter moeilike stryd laat beland - die stryd om die voortbestaan van hierdie inrigting vir hoër onderwys met sy uitgesproke Christelike wetenskap. Die skroewe van die liberale tydsgees, die onsimpatieke universiteitsinrigtings wat beheer oor die eksamens gehad het en die miskenning deur die owerheid, is stadig maar seker aangedraai en teen 1916 lyk die toekoms donker.

Dr. Du Toit en prof. F. Postma met hulle helpers het egter met alle mag die stryd om voortbestaan aangeknoop en toe Wet nr. 12 van 1916, dic sogenaamde gewetensklousule geproklameer word

(17) V.W., ide'm, p. 486.

(18) Sien my Totius - Profect van dir Mooinivier, Kaapstad, 1977, p. 94.

(19) Idrm. 
en waardeur geen binding oor die godsdiens van 'n dosent sou mag bestaan nie, moes daar byna dag en nag gewerk word.

Op 'n keer het Totius sy siening soos volg geformuleer: „Uns bly pal staan by ons standpunt: 'n Christelike nasie is verplig om sy Christelike (spesiaal reformatoriese) dogma oral, ook op die universiteit, kloekmoedig te bely, anders is hy die naam 'Christelik' nie werd nie. Laat ander sogenaamde neutrale skole stig as hulle dit begeer. Ons mag dit nie doen nie. Ons Christennaam mag nie met ons daad bots nie". En dan sluit hy hom aan by 'n woord van die gereformeerde teoloog Voetius wat gesê het: „Wat in die gehoorsaal verkondig word, kom netnou op die mark van die lewe"20).

Oor die rol wat Totius in verband met die inkorporasie van die Literariese Afdeling van die Teologiese Skool by die Universiteit van Suid-Afrika gespeel het en waardeur die P.U.K. tot stand gekom het, kan onmoontlik in hierdie kort artikel volledig vertel word ${ }^{21)}$. Baie interessant is sy eie vertelling in sy „Enkele besonderhede in verband met die inkorporasie", wat by die selfstandigwording van die Universiteit in 1951 gegee is ${ }^{22}$ ).

\section{Totius se pen en sy Universiteit}

Vir bykans 'n halwe eeu was Totius direk betrokke en intens gemoeid met hierdie inrigting, wat eindelik uitgegroei het tot 'n selfstandige Universiteit. Vanaf 1904 tot kort voor sy dood in 1953 het die belangrikheid en ideaal vir die Christelike wetenskap voortdurend sy intense belangstelling geniet. En in hicrdic tyd was dit veral sy vaardige pen wat aktief was. Daaruit het

(20) Idem, p. 66.

(21) Vergelyk hier onder andere J.S. du Plessis se Geskirdenis van die Potchefstruomse Universileit vir CHO, 1919-1951, uitzrgee deur PU vir CHO, 1975, p. 10 e.v.

(22) V.W., idem, p. 112 c.v. 
letterlik 'n stroom literatuur gevloei wat op direkte of indirekte wyse die saak van ons inrigting nie net bevorder het nie, maar gepropageer het. Tientalle artikels oor Christelike onderwys, Christelike wetenskap, Christelike Nasionale onderwys (C.N.O.), die onderwyswetgewing, godsdiensonderrig, ensovoorts het jaar na jaar die bestaansreg van die Potchefstroomse Universiteit bo alle twyfel gestel. „Wat ons nodig het, is seer seker manne met vaste oortuiging, met karakter en wilskrag, wat, as dit daarop aankom, durf nee sê as feitlik die hele wêreld ja sê. En sulke manne word nie in die gehoorsale van die twy fel nie, maar in die skole van die geloof gekweek", verklaar Totius in sy uitmuntende artikel „Wetenskap en twyfel”, wat vandag nog net so aktueel is 23 ).

Sonder dat dit die PU vir CHO een enkele sent gekos het, was die getuienis van Totius na buite en sy prinsipiële leiding na binne deur die jare heen van onberekenbare waarde. Owerheid en volk kon nie anders as om na hom te luister nie; en met hierdie koersvaste onderwysrigting moes daar rekening gehou word.

\section{Die digter se boodskap}

Vir 'n halwe eeu het die profeet sy werk gedoen. Inderdaad die profcet van die Potchefstroomse Universiteit. Maar hy was ook die digter-profeet in wie se werke wetenskap en kuns saamgevloei het as ' $n$ hegte eenheid. En as hy in 1951 die eerste kanselier van die selfstandige PU vir CHO word, dan gebeur daar 'n unieke ding: dit is die kanselier-digter wat sy boodskap gee:

\section{IN U LIG}

\footnotetext{
Geseënd om u lig, o Bron, o Eersbeginsel, eewge Son! U't sonnewesens uitgesaai met transendente vuur gelaai.
}

(23) Idem, p. 94. 
Blink tree hul wit en wonderklaar, maar hulle 't hul geheim bewaar.

Hoeseer ons in dié diepte meet,

ons kan net van 'n, ,ligjaar" weet.

Maar U 't 'n wonderbaarder Lig,

'n Lugter vir ons toegerig.

Die branders is van pure goud, die vlam gelouterd sewevoud.

Dié olievlam, dit was die brand wat uitstraal na 'n donker land.

Verlig dan met dié stralevloed,

o Heer, ons oog en ons gemoed.

Serafs moet voor $u$ oogstraal swig.

Ons sien dié Lugter met sy lig.

Wees dan, o God, gebenedyd,

èn nou èn tot in ewigheid! ${ }^{24}$ )

J. Chris Coetzee, die bekende voormalige rektor en die groot pedagoog van Christelike onderwys het die betekenis van Totius vir sy Universiteit in enkele woorde saamgevat:

„Vir die PU vir CHO was hy die geestelike vader, die koersvaste grondlegger, die getroue voorbidder ... en die eerste kanselier". 25)

(24) Idem, deel 10, p. 465.

(25) Koers, Augustus 1959. 